\title{
VÝVOJ ZÁSUVNÝCH MODULŮ PRO QGIS JAKO SOUČÁST VÝUKY PROGRAMOVÁNÍ V GIS
}

\author{
Kateřina RŮŽIČKOVÁ ${ }^{1}$, Jan RU゚ŽIČKA ${ }^{2}$ \\ ${ }^{1}$ Katedra geoinformatiky, HGF, VŠB-TU Ostrava, 17. listopadu 2172/15, 70800, Ostrava, Česká republika \\ katerina.ruzickova@vsb.cz \\ 2 OpenGeoLabs, Brandlova 1559/7, Chodov, 14900 Praha 4, Česká republika \\ jan.ruzicka.vsb@gmail.com \\ doi: https://doi.org/10.31490/9788024845081-125
}

\begin{abstract}
Abstrakt
Zásuvné moduly pro QGIS znají všichni uživatelé tohoto populárního nástroje. Zároveň je to jedna z cest, jak se seznámit $\mathrm{s}$ jazykem Python a knihovnami pro práci $\mathrm{s}$ prostorovými daty. Programování je nedílnou součástí výuky geoinformatiky na VŠB-TUO, aktuálně je hlavním programovacím jazykem Python. $V$ rámci výuky předmětu Programování II se vyučuje i využití tohoto jazyka pro zpracování prostorových dat. Zásuvné moduly nabízí snadný způsob, jak poměrně rychle umožnit studentům se s danými technologiemi seznámit. $\checkmark$ roce 2020 proběhl zajímavý experiment, kdy se studenti zapojili do vývoje zásuvného modulu, který vyvinuli jiní autoři, konkrétně ze společnosti OpenGeoLabs. Jedná se o zásuvný modul zpřístupňující zdroje prostorových dat $z$ České republiky a Slovenska. Kromě běžných zdrojů WMS a XYZ je součástí i jistá forma zásuvného mechanismu, kdy je možné přidávat i zdroje, které nejsou v podobě služeb, ale třeba jako CSV soubory publikované $v$ prostředí WWW. Studenti se tak seznámili $s$ možností, jak takový mechanismus realizovat. Dále se pak seznámili s technologií git, která umožňuje verzování zdrojového kódu při práci více programátorů na stejném projektu. Realizovali svůj první Fork a Pull request. Což znamená, že si vytvořili kopii (fork) originálního zásuvného modulu, doplnili svůj kód (nebo upravili existující) a pak požádali autory originálního kódu o zavedení nového kódu (pull request). Protože je dnes git považován za základní znalost vývoje aplikací, rozhodně tuto zkušenost zužitkují v praxi. Příspěvek si klade za cíl prezentovat zkušenosti z této spolupráce mezi praxí a akademickou sférou.
\end{abstract}

\begin{abstract}
QGIS plug-ins are familiar to all users of this popular tool. It is also one of the ways to get acquainted with Python and libraries for working with spatial data. Programming is an integral part of teaching geoinformatics at VŠB-TUO. The main programming language is currently Python there. Within the teaching of the subject Programming II, the use of this language for spatial data processing is included. Plug-ins offer an easy way to fairly quickly enable students to become acquainted with the given technologies. It took place in 2020 an interesting experiment in which students participated in the development of a plug-in that was developed by other authors, specifically from company OpenGeoLabs. This is a plug-in module making available sources of spatial data from the Czech Republic and Slovakia. In addition to common sources, WMS and XYZ are also includes a certain forum of the plug-in mechanism, when it is possible to add resources that they are not in the form of services, but for example as CSV files published in the WWW environment. The students have got acquainted with the possibility of implementing such a mechanism. Further then they got acquainted with git technology, which allows source code versioning work with multiple programmers on the same project. They implemented their first Fork and Pull request. This means that they have created a copy (fork) of the original plug-in, they have completed their code (or modified an existing one) and then asked the authors of the original code to introduce the new code (pull request). Because git is now considered a basic knowledge of application development, they will definitely use this experience in practice. The paper aims to present the experience from this cooperation between practice and academia.
\end{abstract}

Klíčová slova: Python; vývoj zásuvného modulu; spolupráce; výuka.

Keywords: Python; plugin development; cooperation; education. 


\subsection{Rozšiřování funkcionality GIS programů}

Nabídku funkcí vaplikacích pro zpracování prostorových dat Ize obvykle rozšiřovat. Je hned několik způsobů, kterými je možné toto řešit, např.:

- Využít uživatelského nástroje, který vytvořil a zveřejnil jiný autor (pokud to jeho licence umožňuje). K universálně zaměřeným GIS programům existují obvykle repozitáře, ve kterých jsou tyto uživatelské nástroje sdíleny. Toto je nejsnazší zpưsob, který vyžaduje pouze znalost, jak takový nástroj v práci využívaného programu spustit.

- Vyvíjet uživatelské nástroje pomocí vizuálního programování - některé programy umožňují vytvořit nový, komplexnější nástroj poskládáním již předdefinovaných nástrojủ. I když jsou obvykle dostupné i základní struktury programovacích nástrojủ jako jsou cykly, či podmínky, jsou možnosti řešení touto cestou omezené. Uživatel pak potřebuje znát prostředí a nástroje pro vizuální programování a mít algoritmizační schopnosti. Znalost programovacího jazyka však není potřeba.

- Vyvíjet uživatelské nástroje pomocí klasického programování, tedy prostřednictvím zápisu $v$ některém z programovacích jazyků. Zde už se uživatel stává vývojářem v pravém slova smyslu. Zde jsou dvě možnosti:

- Vyvíjet v programovacím jazyku, ve kterém je program vytvářen - tedy využívat prímo knihovny daného prostředí. Tato možnost je však obvykle omezena (především u komerčních nástrojů) na uzavřenou skupinu profesionálních vývojářu a rozšiřování základní funkcionality pro všechny uživatele.

- Vyvijet v jiném programovacím jazyku, než ve kterém je program vytvářen - tedy využívat knihovny daného prostředí skrze API (rozhraní). A právě tato možnost je určena pro tvorbu uživatelských nástrojů. Lze tak také využít některý $z$ uživatelsky přivětivějších programovacích jazyků, než ve kterém je psáno jádro programu. Vytvořené nástroje může uživatel bud' použít pro vlastní potřebu, nebo jej sdílet ve veřejných repozitáríich.

Rozsah těchto možností se odvijí od nabídky konkrétního GIS programu a jeho licence, resp. licencí jeho dílčích součástí.

\subsubsection{Sdílený vývoj programátorského projektu}

Vývoj programového vybavení je dlouhodobější aktivita, při níž je výhodné postupně zpracovávat menší částí kódu, které nakonec v souhrnu vytváří požadovanou funkcionalitu. Často je povtřeba obměnit $\mathrm{i} j \mathrm{j}$ ž vytvoření kód, nebo jej přepracovat do jiné podoby. Proto vývojáři využívají verzovací systémy (VSC Version Control System), které zaznamenávají změny souboru nebo sady souborů $v$ čase tak, abyste se mohli později $\mathrm{k}$ určité verzi vrátit. Společná práce skupiny vývojářů na jednom projektu pak vyžaduje specifické př́stupy pro organizaci a sdílení projektu, aby jednotlivé části (soubory) a jejich verze měli přistupné všichni členové týmu a aby je také mohli vytvářet.

Projekty mají své místo v tzv. repozitárích, což jsou úložiště (souborů) projektů s verzovacím systémem. Pokud je vývojářem pouze jedna osoba, pak si vystačí s lokálním repozitářem. Pokud se jedná o vývoj $v$ týmu, pak je výchozím repzitářem sdílený repozitár na serveru. $A v$ této situaci se řeší také přenos záznamů změn mezi lokálními repozitáríi jednotlivých vývojářu a sdíleným repozitářem (tzv. origin). Tento popis prezentuje především centralizované verzovací systémy, kdy je jeden repozitář, který uchovává všechny verzované soubory, a více klientů, kteří umí soubory z centrálního místa získat (EMULATION, 2017). Mezi tyto systémy patří např́íklad systémy CVS, Subversion a Perforce (Chacon a Straub, 2014). Alternativně může být provozován distribuovaný verzovací systém, který eliminuje problém, který může u centralizovaného systému způsobit výpadek jediného centrálního místa. Zde má každý vývojář kompletní kopii celého rezitáře, ze které Ize obnovit projekt při problému $v$ jiném repozitáři. Mezi tyto systémy patří napríklad Git, Mercurial, Bazaar nebo Darcs (Chacon a Straub, 2014).

Práce pak probíhá tak, že se vždy nově napsaný/obměněný kód v nějakém vývojovém prostředí po skončení určitého bloku práce přenese $z$ repozitáre (lokálního, príp. serverového). Při tomto jsou automaticky vyhodnocovány rozdíly mezi stavem projektu ve vývojovém prostředí a lokálním repozitářem, resp. lokálním a serverovým repozitářem. 
Verzovací systém git Ize provozovat pouze lokálně, kdy se řeší změny stavů mezi adresářem systému git a pracovním adresářem (Chacon a Straub, 2014). Častěji se však realizuje serverové rešení pro více uživatelů, kde se stává serverový repozitář tzv. origin a jednotliví vývojáŕi z něj čerpají pro své lokální repozitáře.

Při serverovém-sdíleném režimu Ize využít službu github, která skrze prostředí cloudu umožňuje sdílet repozitáře s git (Devmountain, 2021).

\subsection{QGIS a zásuvné moduly}

Program Quantum GIS (zkráceně QGIS) patří mezi programy s otevřeným kódem a jeho licence GNU GPL je nakloněna jeho volnému využití i vývoji. Uživatelé mohou volit mezi všemi přístupy rozšiřování funkcionality tohoto programu, které byly uvedeny $v$ předešlé kapitole. $V$ repozitáŕi QGIS je aktuálně více než 650 tzv. zásuvných modulů s různým zaměřením. Zásuvné moduly jsou před jejich přidáním do oficiálního repozitáře samozřejmě testovány a kontrolovány ze strany oficiálních vývojářù. I když knihovny pro QGIS jsou vytvářeny prostřednictvím jazyka $\mathrm{C}++$, je $\mathrm{k}$ dispozici $\mathrm{API}$, které umožňuje vývoj zásuvných modulů prostřednictvím Python kódu.

\subsubsection{Zásuvný modul GeoData CZ/SK}

Zásuvný modul GeoData CZ/SK pro QGIS je dílem OpenGeoLabs (OpenGeoLabs, 2020)., která jde cestou otevřených řešení. Na jeho vývoji spolupracovala s OpenGeoLabs v rámci stáže také Stela Tkáčová, studentka Univerzity $v$ Prešově. Tento zásuvný modul má usnadnit uživatelům práci s prípojením geodat, která jsou uvolněna $\mathrm{k}$ veřejnému užití. Tato data mohou být uživatelům zprístupněna více způsoby:

- Pomocí webových mapových služeb. Mohou to být WMS a WMTS. U těchto služeb uživatel potřebuje znát (vyhledat si) lokalizaci služby, její licenci a mít nástroj pro její využití.

- $\quad$ XYZ služby. Jedná se o data v podobě ratrových dlaždic, podobně jako WMTS.

- Zveřejněním linku pro stažení geodat. Tato data si pak uživatel prímo stahuje na svůj počítač.

QGIS umí pracovat využívat a načítat data jak webových mapových služeb, tak data uložená lokálně, či na na nějakém úložišti v síti. Zásuvný modul GeoData CZ/SK má ušetřit uživatelům QGIS práci s vyhledáváním a prippojováním těchto geodat. Na obr.1 je ukázka vyhledání a instalace zásuvného modulu.

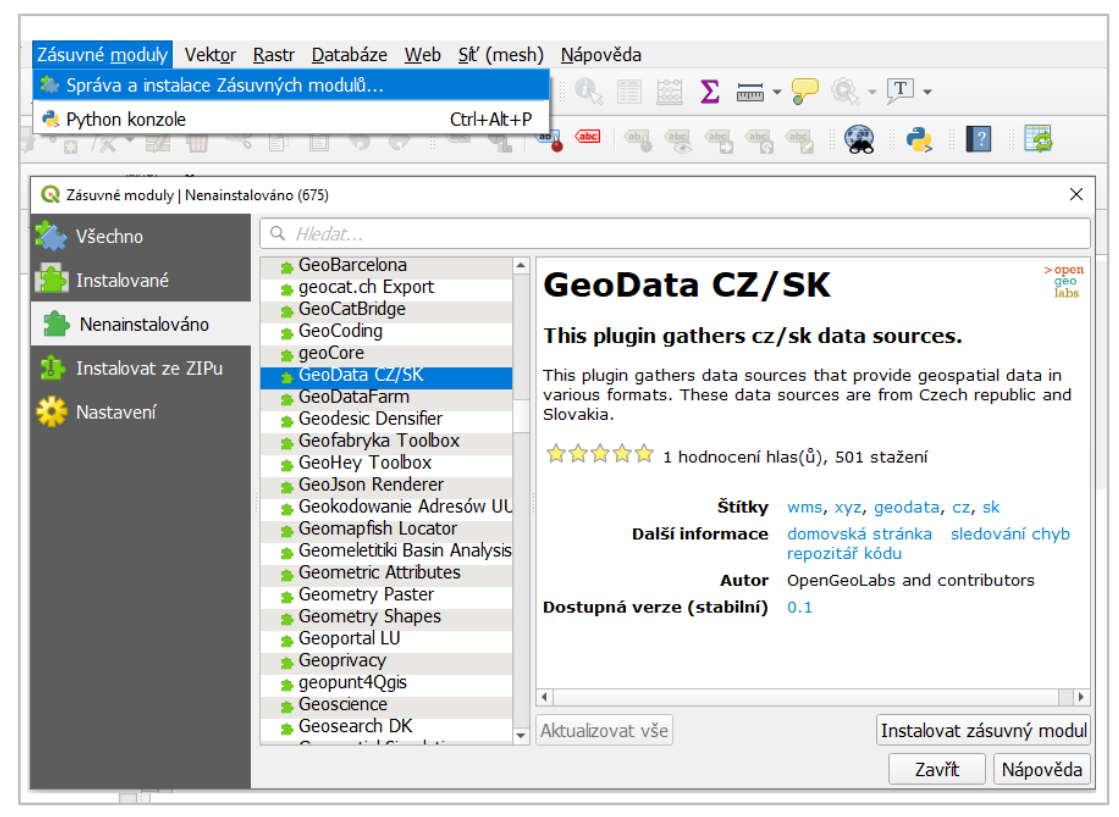

Obr. 1. Ukázka vyhledání a instalace zásuvného modulu

Zpřístupňovaná data mohou být v plošném rozsahu celé ČR, či SR (především data malých měřítek), nebo mohou pokrývat jen menší lokalitu $v$ rámci těchto států. $U$ přístupu $\mathrm{k}$ datům $\mathrm{s}$ menším protorovým rozsahem se může jednat o situaci, kdy datová sada je dostupná jen danou menší lokalitu, nebo jde o zpřístupnění menší části velmi podrobných dat (data velkých měřítek), kde by stahování celého obsahu bylo z hlediska velikosti dat a tvrvání stažení dat náročné. Tato data také obvykle uživatelé využívají pro menší oblasti a 
stahování celé databáze by bylo nadbytečné. Pro tento př́ípad byl naprogramován specifický přístup $\mathrm{k}$ datům. Na obr.2 je zobrazeno dialogové rozhraní zásuvného modulu. Data webových mapových služeb, jako je například datová sada Chráněných území od AOPK Ize přímo vybrat a načíst. Ale např. data ze systému LPIS (veřejný registr půdy) se stahují jen v rozsahu katastrálního území. Mezikrokem při načtení dat je tedy specifikace katastrálního území. Pokud uživatel výběr neuvede, které katastrální území má být načteno, pak se stáhne to, které leží uprostřed aktuálně nastavého plošného rozsahu v mapovém poli.

Je tedy zřejmé, že zásuvný modul GeoData CZ/SK řeší zpřístupnění geodat ve více variantách technologického a procesního řešení.

Aktuálně je $v$ oficiálním repozitáři QGIS první verze toho zásuvného modulu, kde je možné přidávat data od poskytovatelů jako ČÚZK, CENIA, MAPY.CZ, AOPK atd. (viz obr.2). Vývojáři připravili také velmi hezkou vizualizaci dat z MAPY.CZ a DEM $5 G$ - viz obr.3.

Na rozšíření nabídky slovenských datových sad ZBGIS se momentálně pracuje. $V$ druhé verzi zásuvného modulu, která bude vydána $v$ nejbližší době, již bude slovenských geodat mnohem více. $O$ velkém zájmu vývoje tohoto modulu svědčí i zapojení dalších vývojářů ze Slovenska (Martin Dobiáš, Peter Piesecký, Miloslav Michalko, Jana Michálková). Řeší se zpřesnění transformačních klíčů S-JTSK pro ČR a SR, filtrace $v$ rozsáhlejší nabídce datových sad podle klíčových slov a dlaší rozšiření funkcionality.

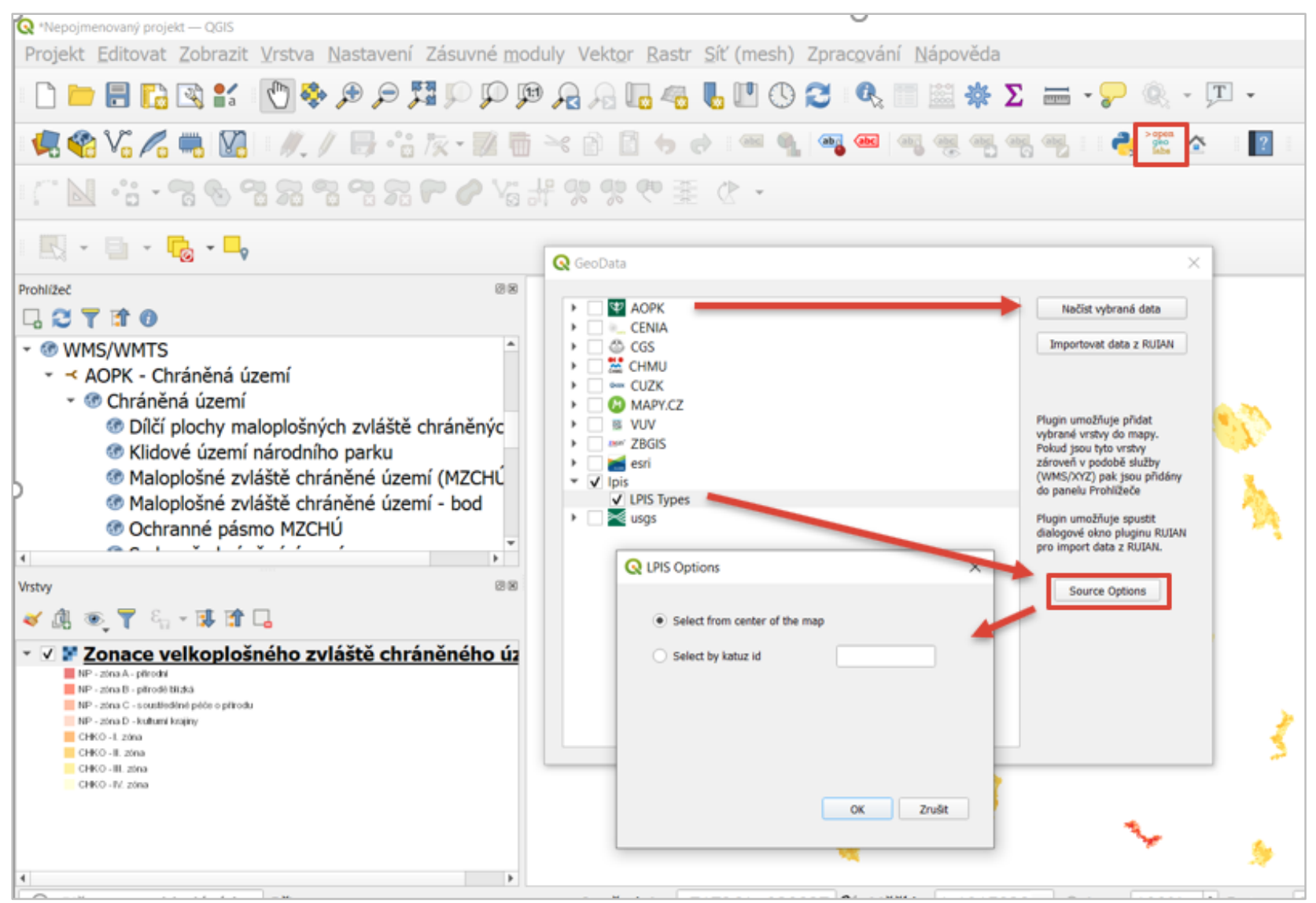

Obr. 2. Ukázka dialogového rozhraní zásuvného modulu GeoData CZ/SK s naznačením způsobů jeho užití 


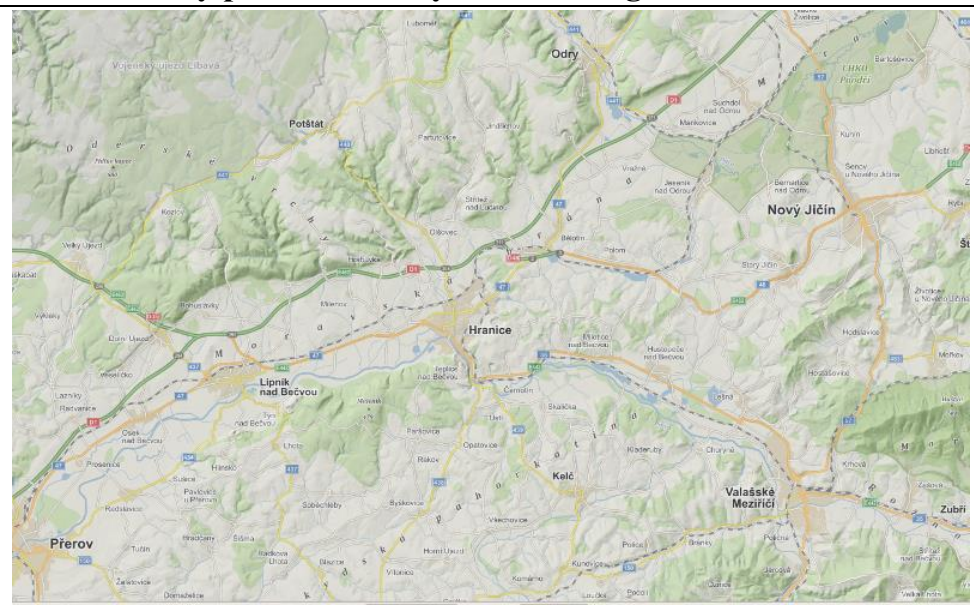

Obr. 3. Ukázka společné vizualizace dat z MAPY.CZ a DEM 5G

\subsection{Výuka programování na Katedře geoinformatiky VŠB-TUO}

I když programování není mezi studenty vždy tím nejoblíbenějším předmětem, jako technická škola se snažíme, aby naši absolventi nebyli jen pouhými uživateli GIS, ale aby byli schopni automatizovat procesy zpracování geodat, rozvíjet stávající nástroje pro zpracování geodat, případně vytvářet i nástroje vlastní.

$\checkmark$ průběhu let sledujeme trendy ve využívání programovacích jazyků. Jestliže jsme tedy začali před více než 20 lety s výukou ve VisualBasic a $\mathrm{C++}$, postupně jsme přešli na $\mathrm{C \#}$ a následně se přešlo na Java a Python, které jsme několik let učili současně. Výuka dvou programovacích jazyků (a $k$ tomu ještě $i$ značkovacích jazyků), ale byla pro studenty dost náročná. Rozhodli jsme se tedy netříštit úsilí studentů mezi více programovacích jazyků, ale spíše rozvinout jejich schopnosti v jednom programovacím jazyku na vyšší úroveň a především v návaznosti více na GIS aplikace. $V$ souboji mezi jazyky Java a Python nakonec vyhrál Python, který je v současnosti nejvyužívanějším programovacím jazykem (Data Is Beautiful, 2019). Navíc je využíván príi práci s QGIS (PyQGIS) i pro práci s knihovnami od ESRI (ArcPy) (Robinson a kol., 2019).

Co se týče nastavení úrovně složitosti a komplexnosti rešení, můžeme využít návaznosti několika programovacích předmětů, které na sebe navazují. Po zvládnutí všeobecných základů jazyka Python se tak můžeme přesunout $\mathrm{k}$ práci s knihovnami pro geodata.

Konkrétní náplň programovacích předmětů vychází z požadavků firem, které přijímají naše studenty jako zaměstnance. $Z$ nich vyplývá, že je pro ně podstatné i to, zda jsou schopni pracovat v týmu, tedy na stejném projektu společně $s$ dalšími lidmi. $V$ rámci vývoje nástrojů to znamená schopnost sdílet kód projektu s ostatními členy týmu, přispívat do něj a koordinovat tyto aktivity pomocí řízených prístupů, verzování a postupného skládání částí kódu. Což jsou přístupy, které přináší práce na nějakém rozsáhlejším dlouhodobějším projektu, který často školy v rámci časově omezené výuky jen stěží mohou realizovat. Proto jsme privítali možnost prípojit se k projektu OpenGeoLabs při vývoji zásuvného modulu GeoData CZ/SK.

\section{METODIKA}

Možnost zapojení studetů do vývoje zásuvného modulu GeoData CZ/SK byla podmíněna jejich schopností práce $v$ Python $s$ využizím git. Práci s Python si již osvojili v rámci výuky programování. Práce s verzovacím systémem git pro sdílený projekt však pro ně byla novinkou. Stejně tak jako řešení zásuvného modulu. Proto prvním krokem bylo seznámení s principy git a funkcionalitou kódu od OpenGeoLabs. I když se studenti nezapojili přímo do rozšíření funkcionality zásuvného modulu, bylo nezbytné, aby pochopili, jakým způsobem je řešena struktura projektu a zpřístupňování různých typů datových zdrojů. Pouze tak mohli poté přidávat ten správný kód na správné místo a správným způsobem. Pro přidávání datových zdrojů bylo potřeba také vyhledat informace o těchto zdrojích.

Průběh zpracování tedy probíhal v těchto krocích:

- Seznámení s aktuálním stavem zásuvného modulu, jeho strukturou a principem jeho fungování 
- Sběr potřebných údajů o datových zdrojích (způsob jejich zpřístupnění, jejich struktura, datový formát, souřadnicový systém, licence, vhodný způsob stylování vizualizace)

- Zakomponování do zásuvného modulu

- Stažení projektu zásuvného modulu z repozitáře OpenGeoLabs do lokálního repozitáře

- Doplnění zásuvného modulu o části zpřístupňující další datové sady - lokální práce s git a s vlastními repozitári

- Testování a odladění nových/přidaných částí zásuvného modulu

- Odeslání nových/přidaných částí zásuvného modulu z repozitářů studentů na github OpenGeoLabs

- Doladění dle požadavků OpenGeoLabs. $V$ případě nedostatků nebyl Pull request prǐijat, ale $\vee$ rámci komentáře byl autor vyzván $\mathrm{k}$ úpravě nebo doplnění některých částí.

Systém koordinace práce prezentuje obr.3. Pomocí př́íkazu Fork si studenti stáhli kopii projektu zásuvného modulu $z$ repozitáře OpenGeoLabs (Upstream) do svého vlastního repozitáre (Origin). Ve vývojovém prostředí PyCharm poté využili verzovací systém git, kde se připojili ke svému repozitáŕi. Rozšíření a úpravy kódu si poté ukládali z pracovního adresáře do adresáře systému git pomocí tzv. commits. Ucelejší bloky práce si pak přenášeli do svého repozitáře (Origin) pomocí Push příkazu. Výsledek své práce nakonec odeslali do repozitáre OpenGeoLabs (Upstream) pomocí Pull Request, tedy žádosti o zapracování změn.

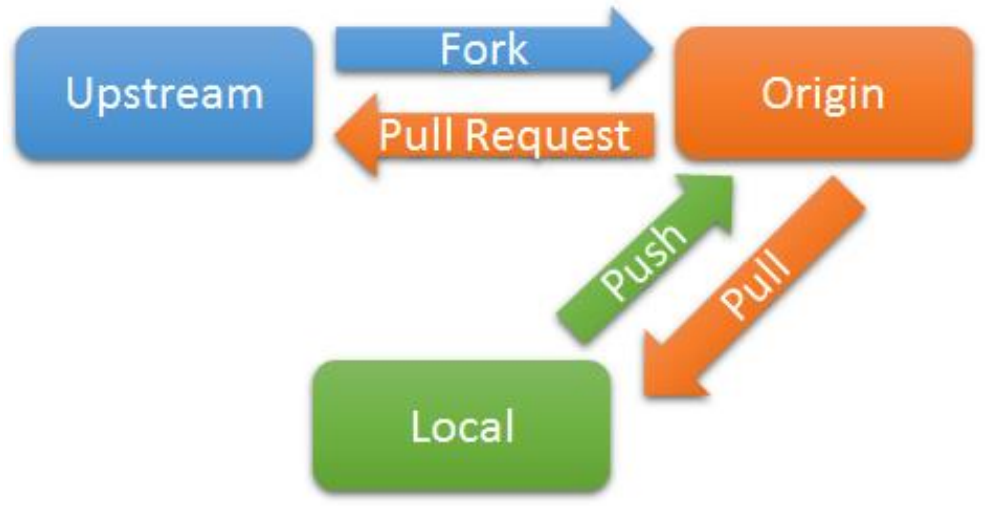

Obr. 4. Princip přenosů projektu na github mezi repozitáři (Abel, 2015)

\section{VÝSLEDKY}

Každý ze studentů rozširíil zásuvný modul GeoData CZ/SK pro QGIS o jeden datový zdroj ve formě WMS zdroje a jeden datový zdroj, který je řešen stahováním balíku dat na lokální disk. Cíleno bylo na WMS AOPK (AOPK, 2021) a datové sady Data50 z ČÚZK (ČÚZK, 2021).

Ze strany Katedry geoinformatiky však bylo hlavním prínosem samotné zapojení studentů do vývoje, který vede firma $z$ praxe. Tedy práce na reálném a prakticky využitelném projektu. To vedlo ke zvýšení motivace studentů a následně i pocitu sounáležitosti a hrdosti z výsledku práce. Díky zapojení do vývoje open source už ted' mohou sledovat šiřii okruhu uživatelů zásuvného modulu, na kterém se podíleli.

Studenti měli možnost spolupracovat s profesionály a komunikovat $s$ jinými osobami, než jen $s$ akademiky. Toto vneslo trochu jiný pohled a prístup, než na jaký jsou zvyklí ze školského prostředí. Kromě osvojení si práce s knihovnami pro práci s prostorovými daty a použivání git tedy považujeme za hlavní výstup neocenitelné zkušenosti studentů.

\section{ZÁVĚR}

Experiment se zapojením většího množství studentů do reálného projektu v rámci běžné výuky se úspěšně podařilo dokončit. Zásuvný modul byl takto rozšiřen o další zdroje a studenti získali cenné zkušenosti. Po pozitivních zkušenostech plánujeme v letošním roce tuto aktivitu zopakovat i s dalším ročníkem studentů. 


\section{LITERATURA}

Abel, A. (2015) Fixing a Pull Request from Master. Fixing a Pull Request from Master | Passion for Coding (abel.nu). Available at: https://coding.abel.nu/2015/03/fixing-a-pull-request-from-master/ (cit 10.3.2021)

AOPK (2021) Poskytování dat. Dostupné online: https://data.nature.cz/ (cit 10.1.2021)

ČÚZK (2021) Data50. Dostupné online: https://geoportal.cuzk.cz/ (cit 10.1.2021)

Data Is Beautiful (2019) Most Popular Programming Languages 1965-2019. 7. 10. 2019. Available at: https://www.youtube.com/watch?v=Og847HVwRSI. (cit. 12.2.2021)

Devmountain (2021) Git vs. GitHub: What's the Difference? Available at: https://blog.devmountain.com/gitvs-github-whats-the-difference/ (cit. 12.2.2021)

Emulation Software Technologies Ltd. (2017) GIT. March 30, 2017. Available at: https://emulationsofttech.wordpress.com/2017/03/30/git/. (cit. 10.3.2021)

Chacon, S. and Straub, B. (2014) Pro Git. Apress. https://git-scm.com/book/cs/v2 (cit. 10.3.2021)

OpenGeoLabs (2020). GeoData CZ/SK. Dostupné online:

https://github.com/OpenGeoLabs/czech_slovak_freegeodata (cit. 10.3.2021)

Robinson, A., C., MacEachren, A., Bacastow, T. (2019) Overview of Programming Languages for GIS. The Pennsylvania State University. Available at: https://www.e-education.psu.edu/geog583/node/67. (cit. 12.12.2020)

Sherman, G. (2018) The PyQGIS Programmer's Guide. Extending QGIS 3.x with Python 3. Locate Press LLS. Chugiak. 247p. ISBN 987-0998547725. 